A reviewer usually likes to point out omissions, but the only one as yet noticed is that of the very recent experiences of Wilbur Wright and his brother. And evidently there are two accounts of Degen's attempts, of which the more improbable one is here given. According to the other, his machine would not rise until he attached it to a balloon.

The illustrations are excellent, but it may be as well to warn the reader that when he sees a picture of an aëronaut sailing over houses, trees, mountains, rivers and even pyramids in an extraordinary looking machine, it is not to be supposed that the journey depicted was ever performed, or even that the machine was necessarily constructed in the forms shown. Readers of the "Histoire des Ballons" will remember the fantastic figures of flying men in that book and will not be surprised to find a few of the types reproduced here, but now that experiments have been successfully made in directed navigation through the air, it would be well if some indication could be given on illustrations in future books showing at a glance whether the flight which they depict is a real flight or a mere flight of the imagination.

G. H. BRYAN.

\section{TERRESTRIAL MAGNETISM.}

\section{United States Magnetic Declination Tables ant} Isogonic Charts for 1902. By L. A. Bauer. Pp. 405. (Washington: Government Printing Office, 1902.)

THE activity of the United States Coast and Geodetic Survey Department in carrying out a magnetic survey of the States and outlying territories has long been a subject of interest to magneticians, and in this book we have the first complete information on the results of that survey up to January I, 1902, as regards the one element magnetic declination.

Tables, giving every observation made, occupy 142 pages, including positions, date of observation, values observed and values reduced to 1902 , followed by the name of the observer or authority. The succeeding 138 pages are devoted to descriptions of the magnetic stations occupied by the Survey between I $88 \mathrm{I}$ and July, I902.

The accompanying chart of "Lines of Equal Magnetic Declination" is based on the results plotted at about 5000 points, embodying all the latest declination data of known value. The lines are true isogonals, drawn with considerable sinuosities, representing the results of actual observation and showing disturbances from normal values, but as these latter have not yet been calculated, the amount of disturbance and the centres of disturbance have not been ascertained. The chart for Alaska gives normal lines of the magnetic declination calculated from all available observations, there being too few of the latter from which to draw true isogonals.

A welcome addition to the tables and charts will be found in the opening chapter under the heading "Principal Facts relating to the Earth's Magnetism," showing our present state of knowledge of terrestrial magnetism and the vast field open to future observers and students of that branch of science.

$$
\text { No. } 1735 \text {, voL. 67] }
$$

In this chapter, the evolution of the compass is treated boldly and agreeably with the evidence of the best authorities, and one rather looks for the date and the name of the first person who applied that very important addition to the mariner's compass-its suspension in gimbal rings. It is clear that the use of this suspension was implied by Pedro de Medina in his "Arte de Navigacion" of 1545, and was accurately described as part of a compass by Martin Cortés in his "Arte de Navigacion" of 1556 , but they leave the inventor's name in obscurity.

Turning to the subject of Gilbert's work, "De Mag. nete," the author remarks on the "intolerance and lack of appreciation of the work of his predecessors" shown by Gilbert. When, however, one reads the account given by the latter of the mass of ignorance and superstition he had to battle with and relinquish to "the moths and worms"-such as the medicinal properties of the lodestone and its uses as a detector of immorality and many other "vanities"-we can hardly wonder at their begetting a spirit of intolerance in him. Even "the Onyon and Garlick myth" which he so denounced was revived in 1885 by an inventor who proposed the use of the juice of the common Dutch red onion as a magnetic screen. Possibly some readers of the present work will think the author has not quite done full justice to Gilbert.

On p. 6o, the authority of the late Prof. Eschenhagen is given for the statement that the effects of earthquakes on the magnetic needle are "entirely mechanical." As the more recent investigations of Prof. Milne point to an opposite conclusion, there is evidently room for further inquiry as to how far the disturbances observed are due to magnetic causes or not.

In the article on magnetic observatories, some useful details are given of the structure of the magnetic observatory at Cheltenham, Maryland, where, although it is built entirely above ground, the diurnal change of temperature has been reduced to a few tenths of a degree, and further reduction is looked for.

In conclusion, it may be remarked that some of the illustrations are taken from rare prints, and their reproduction cannot fail to be of great interest to many who may not have the means of seeing the originals. Pleased as the investigator may be with the valuable results contained in this book, he will look forward with enhanced interest to a similar publication relating to the magnetic inclination and force, both of which have been so extensively observed in the United States.

\section{OUR BOOK SHELF.}

Letters on Reasoning. By J. M. Robertson. Pp. xxviii +248. (London: Watts and Co., I902.)

THis book is in the form of letters addressed to the author's children, and is lucidly and fluently written. Mr. Robertson's counsels upon the duty and importance of clear thought and scrupulous candour in reasoning are excellent, and it is to be hoped the children to whom the letters are addressed will profit by them. It is a pity Mr. Robertson does not always follow his own good advice. In the constant polemic against theism, to which he recurs in chapter after chapter, he often unconsciously misrepresents the case against which he is 